\title{
Multiple myeloma in Niger Delta, Nigeria: complications and the outcome of palliative interventions
}

\author{
Ogbonna Collins \\ Nwabuko ${ }^{1,2}$ \\ Elizabeth Eneikido Igbigbi ${ }^{3}$ \\ Innocent ljezie \\ Chukwuonye ${ }^{4}$ \\ Martin Anazodo Nnoli ${ }^{5}$ \\ 'Department of Haematology, \\ Federal Medical Center, Umuahia, \\ 2Department of Haematology, \\ College of Health Science, Abia \\ State University, Aba, Abia State, \\ ${ }^{3}$ Department of Haematology, Blood \\ Transfusion and Immunology, Faculty \\ of Basic Medical Sciences, University \\ of Port Harcourt, Port Harcourt, \\ ${ }^{4}$ Department of Internal Medicine, \\ Federal Medical Center, Umuahia, \\ ${ }^{5}$ Department of Anatomic Pathology, \\ University of Calabar, Calabar, Nigeria
}

This article was published in the following Dove Press journal:

Cancer Management and Research

22 May 2017

Number of times this article has been viewed

Background: Multiple myeloma (MM) is one of the hematological malignancies that require palliative care. This is because of the life-threatening nature and the suffering associated with the illness. The aim of this study is to bring to the fore the complications experienced by people living with $\mathrm{MM}$ in the Niger-Delta region of Nigeria and the outcome of various palliative interventions.

Methods: This was a 10-year multi-center retrospective study of 26 patients diagnosed and managed in three major centers in the Niger-Delta region of Nigeria from January 2003 to December 2012. Information on the clinical, laboratory, radiological data, and palliative treatment was obtained at presentation and subsequently at intervals of 3 months until the patient was lost to follow-up.

Result: The mean duration from onset of symptoms to diagnosis was 13.12 months $(95 \%$ CI, 6.65-19.58). A total of 16 (61.5\%), eight (30.8\%), and two subjects (7.7\%) presented in Durie-Salmon (DS) stages III, II, and I, respectively. The complications presented by patients at diagnoses included bone pain (84.6\%), anemia (61.5\%), nephropathy (23.1\%), and hemiplegia (35\%). All the patients received analgesics, while 50.0\% received blood transfusion, $56.7 \%$ had surgery performed, $19 \%$ had hemodialysis, and 3.8\% received radiotherapy. A total of $10(38 \%)$ patients benefited from bisphosphonates (BPs). A total of $57.6 \%$ of patients were on melphalan-prednisone (MP) double regimen, while $19 \%$ and $8 \%$ patients were on MP-thalidomide and MP-bortezomib triple regimens, respectively. A total of $3.8 \%$ of patients at DS stage IIIB disease had autologous stem-cell transplantation (ASCT). Only $7.6 \%$ of the myeloma patients survived up to 5 years post diagnosis. The overall mean survival interval was 39.7 months ( $95 \%$ CI, 32.1-47.2).

Conclusion: Late diagnosis and inadequate palliative care account for major complications encountered by MM patients in the Niger-Delta region of Nigeria. This could be responsible for the poor prognostic outcome and low survival interval of MM individuals in this region. There is, therefore, a need to improve the quality of palliative care received by myeloma patients in this region. This is achievable via provision of relevant and affordable health care facilities for diagnosis and treatment of the disease.

Keywords: multiple myeloma, palliative care, melphalan-prednisone, bone marrow plasma cells, autologous stem-cell transplantation, Niger Delta

\section{Introduction}

Multiple myeloma (MM) is a malignancy of plasma cells that results in an overproduction of light and heavy chain monoclonal immunoglobins. ${ }^{1}$ It is one of the commonest hematological malignancies of public health importance globally. It accounts
Correspondence: Ogbonna Collins Department of Hematology, Federal Medical Center, Aba Road, PMB 700I, Umuahia, Abia State, Nigeria

Tel +2348037046537

Email ogbollins2002@yahoo.com 
for $10 \%-15 \%$ of all lymphohematopoietic cancers (LHCs), $0.8 \%-1 \%$ of all cancer diagnoses, $27 \%$ of all LHC deaths, and $0.9 \%-2 \%$ of all cancer-related mortalities. ${ }^{2-4}$ However, there is a dearth of data on the epidemiology of MM in the African continent due to poor financial resources and poor case ascertainment. The international and ethnic variability report on $\mathrm{MM}$ shows a higher incidence rate among African Americans. ${ }^{5}$ The estimated US age-adjusted incidence rate in African Americans is 11.1/100,000/year as compared to $5.3 / 100,000 /$ year for Caucasians. Zimbabwe, an African country, has an incidence rate of $\sim 3.5 / 100,000 /$ year. $^{6}$ Although the incidence rate is not known in Nigeria, MM represents $\sim 8.2 \%$ of all hematological malignancies. ${ }^{7}$

The cause of MM has not yet been identified. However, recent studies have identified factors implicated as potentially etiologic for MM. ${ }^{1}$ These factors include increasing age (>65 years), male gender, black race, positive family history of MM or LHC (genetic influence), and monoclonal gammopathy of undetermined significance (MGUS), the hypothesized precursor of MM. ${ }^{1,6,7}$ Other possible risk factors for MM include obesity, ${ }^{8}$ low fish consumption, low green vegetable consumption, and previous history of viral diseases such as herpes zoster or acquired immunodeficiency syndrome (AIDS). ${ }^{1,9}$ Suspected risk factors that have not provided consistent evidence of causal association with MM include exposures to smoking, alcohol, pesticides (herbicides), organic solvents (i.e., petrol workers and painters), radiation (i.e., nuclear workers and occupational therapists), asbestos, and allergic conditions. ${ }^{1}$

MM poses a diagnostic dilemma to the surgeons and physicians because of the late presentations and frequent skeletal manifestations. Consequently, misdiagnosis and poor palliative care are often common contributory factors to the poor prognosis in Nigeria and other sub-Saharan African countries. ${ }^{10,11}$

According to the International Myeloma Working Group, the diagnosis of MM is based on a constellation of hematologic, immunologic, histologic, and radiographic features. The clinical assessment of myeloma-related endorgan impairment in the presence of serum M-protein and bone marrow plasma cells (BMPCs) is strongly suggestive of MM. ${ }^{12,13}$

However, making a definitive diagnosis of $\mathrm{MM}$ is not easy in poorly equipped centers such as those found in the Niger-Delta region of Nigeria. When diagnosis is made at an advanced stage of the disease, there is no proper palliative care in place to improve the quality of life of the victims, hence worsening the outcome.
The World Health Organization (WHO) defines palliative care as an approach that improves the quality of life of patients and their families facing problems associated with life-threatening illness through the prevention and relief of their sufferings by means of early identification, assessment, and treatment of pain and other problems, including physical, psychosocial, and spiritual. "Palliative care" as used in the context of management of MM connotes "supportive and definitive interventions". ${ }^{14,15}$

This study is aimed at giving insight on the challenges of managing MM in Nigeria, a sub-Saharan African country.

\section{Methods}

This was a 10 -year retrospective study carried out from January 2003 to December 2013 at the University of Port Harcourt Teaching Hospital (UPTH), Braithwaite Memorial Specialist Hospital (BMSH), Rivers State, and Federal Medical Center (FMC), Umuahia, Niger Delta, Nigeria. Ethical clearance was obtained from the ethics committees of UPTH, BMSH, and FMC in keeping with the guidelines of the Declaration of Helsinki (1964) and Good Clinical Practice. Written informed consent was not obtained from the patients before enrollment because of the retrospective nature. However, the patients' identities were kept confidential. The Niger-Delta region is an oil-rich region made up of eight states in Nigeria. UPTH is a 1000-bed hospital, while BMSH and FMC are 200- and 350-bed hospitals, respectively. They serve as referral centers for inhabitants of Rivers, Abia, and their neighboring states of Bayelsa, Edo, Cross Rivers, Delta, Akwa Ibom, and Imo. These states account for $>20 \%$ of the Nigerian population based on 1991 population census. ${ }^{16}$ Demographic, clinico-immunologic, radiologic, and therapeutic data were obtained from case notes and interviewer-structured questionnaires at presentation and at intervals of 3 months subsequently. The Eastern Cooperative Oncology Group (ECOG) scale for measuring performance status on a scale (from 0 to 4 ) was applied to the patients with age-adjustment index. ${ }^{17}$

A minimum of two major criteria, one major criterion plus one minor criterion, or three minor criteria always including "a" and "b" as shown in Table 1 was used in making a diagnosis. The major criteria included: 1) plasmacytoma on tissue biopsy; 2) bone marrow infiltration with $>30 \%$ BMPCs; and 3) monoclonal globulin spike. The minor criteria included: 1) 10-30\% bone marrow plasmacytosis; 2) paraprotein less than the level defined in major criteria; 3) lytic bone lesions; and 4) normal immunoglobin levels., ${ }^{418}$ Durie-Salmon (DS) clinical staging system was used in staging the subjects with 
Table I Criteria for the diagnosis of MM

\begin{tabular}{|c|c|c|}
\hline \multirow[t]{3}{*}{ Major criteria } & I & Plasmacytoma on tissue biopsy \\
\hline & II & Bone marrow infiltration with $>30 \%$ BMPCs \\
\hline & III & $\begin{array}{l}\text { Monoclonal globulin spike (paraprotein) } \\
\text { on serum electrophoresis ( } \mathrm{lgG}>35 \mathrm{~g} / \mathrm{L} \\
\text { and } \operatorname{lgA}>20 \mathrm{~g} / \mathrm{L} \text { ) or on concentrated urine } \\
\text { electrophoresis }(>\mid \mathrm{g} / 24 \mathrm{~h} \text { or kappa or lambda } \\
\text { light chain) }\end{array}$ \\
\hline \multirow[t]{4}{*}{ Minor criteria } & A & $\begin{array}{l}\text { Bone marrow infiltration with } 10-30 \% \text { plasma } \\
\text { cells }\end{array}$ \\
\hline & B & Paraprotein less than the level defined earlier \\
\hline & C & Lytic bone lesions \\
\hline & $\mathrm{D}$ & Normal $\lg M<0.5 \mathrm{~g} / \mathrm{L}, \lg \mathrm{A}<\mathrm{lg} / \mathrm{L}$ or $\lg \mathrm{g}<6 \mathrm{~g} / \mathrm{L}$ \\
\hline
\end{tabular}

Abbreviations: MM, multiple myeloma; BMPC, bone marrow plasma cell; $\lg G$, immunoglobin $G$; IgA, immunoglobin $A$; IgM, immunoglobin $M$.

MM. ${ }^{18,19}$ The DS staging system is shown in Table 2. The criterion for inclusion was based on the diagnosis of MM.

Therapeutic intervention was based on two major categories of treatment: 1) the non-definitive palliative interventions (made up of pharmacological/medical interventions and surgery interventions, which are also known as supportive care and 2) definitive palliative interventions, which are also known as specific care (including anti-myeloma chemotherapy, radiotherapy, and stem-cell transplantation). These interventions are illustrated in Tables 3 and 4.

\section{Data analysis}

Data were analyzed using the Statistical Package for the Social Sciences (SPSS) version 16. All statistical data were

Table 2 DS staging system

\begin{tabular}{l} 
I. All of the following \\
Hemoglobin $>10.5 \mathrm{~g} / \mathrm{dL}$ \\
Serum calcium normal \\
X-ray showing normal bone structure or solitary bone plasmacytoma \\
only \\
Low paraprotein levels \\
IgG $<50 \mathrm{~g} / \mathrm{L}$ \\
IgA $<30 \mathrm{~g} / \mathrm{L}$ \\
Urinary light chain $<4 \mathrm{~g} / 24 \mathrm{~h}$ \\
2. Fitting neither stage I or stage III \\
3. One or more of the following: \\
Hemoglobin $<8.5 \mathrm{~g} / \mathrm{dL}$ \\
Serum calcium $>3 \mathrm{mmol} / \mathrm{L}$ \\
Advanced lytic bone lesions (more than three lytic lesions) \\
High paraprotein levels \\
IgG $>70 \mathrm{~g} / \mathrm{L}$ \\
IgA $>50 \mathrm{~g} / \mathrm{L}$ \\
Urinary light chain $>12 \mathrm{~g} / 24 \mathrm{~h}$ \\
Sub-classification \\
A. Serum creatinine $<170 \mu \mathrm{mol} / \mathrm{L}$ \\
B. Serum creatinine $\geq 170 \mu \mathrm{mol} / \mathrm{L}$ \\
\hline Abbreviations: DS, Durie-Salmon; IgG, immunoglobin G; IgA, immunoglobin A.
\end{tabular}

Table 3 Non definitive palliative interventions (supportive care)

\begin{tabular}{|c|c|c|c|}
\hline \multicolumn{4}{|c|}{ Pharmacological/medical palliative interventions } \\
\hline $\begin{array}{l}\text { Serial } \\
\text { number }\end{array}$ & $\begin{array}{l}\text { Pharmacological/medical } \\
\text { interventions }\end{array}$ & Frequency $(n)$ & Percentage \\
\hline $\mathrm{I}$ & Analgesics (opiates, i.e., oral) & 26 & 100 \\
\hline 2 & $\begin{array}{l}\text { BPs (pamidronate, zoledronic } \\
\text { acid) }\end{array}$ & 10 & 38 \\
\hline 4 & $\begin{array}{l}\text { Erythroid growth factors } \\
\text { (rhEPO) }\end{array}$ & 10 & 38 \\
\hline 5 & Blood transfusion & 13 & 50 \\
\hline 6 & Hemodialysis & 5 & 19 \\
\hline \multicolumn{4}{|c|}{ Surgical interventions } \\
\hline $\begin{array}{l}\text { Serial } \\
\text { number }\end{array}$ & Surgery performed & Frequency (n) & Percentage \\
\hline \multirow[t]{3}{*}{$\mathrm{I}$} & Orthopedic & 12 & 46.1 \\
\hline & Thoracolumbar jacket & 3 & 11.5 \\
\hline & ORIF & 9 & 34.6 \\
\hline 2 & Craniotomy & 1 & 3.8 \\
\hline 3 & $\begin{array}{l}\text { Resection of plasmacytoma of } \\
\text { jaw bone }\end{array}$ & I & 3.8 \\
\hline 4 & $\begin{array}{l}\text { Resection of solitary } \\
\text { plasmacytoma of urinary }\end{array}$ & $I$ & 3.8 \\
\hline Total & & 15 & 57.5 \\
\hline
\end{tabular}

Abbreviations: BP, bisphosphonate; rhEPO, recombinant human erythropoietin; ORIF, open reduction and internal fixation.

entered and analyzed using the SPSS statistical software version 16.0 (IBM Corporation, Armonk, NY, USA).

\section{Result}

\section{Clinical characteristics}

A total of 26 patients (18 males and eight females, male to female ratio 2.3:1, $p<0.05$ ) with MM were identified during the retrospective study. The median age of our study population was $62.5 \pm 18.5$ years with $7.7 \%$ of the patients $<50$ years. The median duration from the onset of symptoms to diagnosis was 13.12 months ( $95 \% \mathrm{CI}, 6.65-19.58$ ). In all, $16(61.5 \%)$, eight (30.8\%), and two (7.7\%) subjects presented in DS stages III, II, and I, respectively. The major clinical complications presented at diagnosis were chronic bone pain (84.6\%), anemia (61.5\%), weakness $(50 \%)$, pathological fracture (42.3\%), nephropathy (23\%), constipation (19.2\%), and inability to walk (35\%).

\section{Laboratory findings}

The mean hemoglobin concentration was $7.8 \pm 5.1 \mathrm{~g} / \mathrm{dL}$, erythrocyte sedimentation rate (ESR) was $126.9 \pm 59.0 \mathrm{~mm} / \mathrm{h}$, BMPC concentration was $38.5 \pm 33.5 \%$, serum creatinine concentration was $256 \pm 192.5 \mu \mathrm{mol} / \mathrm{L}$, serum calcium concentration was $2.51 \pm 0.8 \mathrm{mmol} / \mathrm{L}$, and serum albumin concentration was $36 \pm 9.3 \mathrm{~g} / \mathrm{dL}$. A total of $25 \%$ of the patients had immunoglobin A (IgA) myeloma, while $75 \%$ 
Table 4 Chemotherapeutic intervention and the mean survival intervals

\begin{tabular}{lllllll}
\hline Serial number & $\begin{array}{l}\text { Chemotherapy } \\
\text { agent }\end{array}$ & Frequency (n) & Percentage & $\begin{array}{l}\text { Mean survival } \\
\text { interval (months) }\end{array}$ & $\begin{array}{l}\text { p-value } \\
\text { with MP }\end{array}$ & $\begin{array}{l}\text { Remarks } \\
\text { I }\end{array}$ \\
\hline MP & 15 & 57.7 & 42 & - & - \\
2 & MPT & 5 & 19.7 & 48 & 0.33 & NS \\
3 & VMP & 2 & 7.7 & 70 & 0.23 & NS \\
4 & VAD & 2 & 7.7 & 8 & Null \\
5 & CP & $1 *$ & 3.8 & 3 & Null \\
6 & CVAP & $1 *$ & 3.8 & 2 & & \\
Total & & 26 & 100 & 39.65 & \\
\hline
\end{tabular}

Note: *Data are insufficient when the number of observations is equal to one $(n=l)$ for test. '-' indicates nil.

Abbreviations: MP, melphalan-prednisone; MPT, melphalan+prednisolone+thalidomide; NS, not significant; VMP, melphalan+prednisolone+bortezomib or Velcade; VAD, vincristine+adriamycin+dexamethasone; CP, cyclophosphamide+prednisolone; CVAP, cyclophosphamide+vincristine+adriamycin+prednisolone; S, significant.

had immunoglobin G (IgG) myeloma. In all, 14 (70\%) out of 20 patients who did skeletal survey had osteogenic bone lesions.

\section{Palliative interventions}

\section{Pharmacological/medical interventions}

All the patients received analgesics (opiates and nonsteroidal anti-inflammatory drugs [NSAIDs]) and hematinics, excluding folic acid. A total of $10(38 \%)$ patients benefited from bisphosphonates (BPs; such as pamidronate, aldronic acid, and zoledronic acid) and erythropoietin (erythroid growth factor), while three (11.4\%) patients received granulocytecolony stimulating factor (G-CSF). In all, 13 (49.4\%) patients received blood transfusion (ranging 2-25 units). Three (11.5\%) patients with severe anemia refused blood transfusion based on religious ground. Five (19\%) patients with evidence of kidney involvement had hemodialysis (Table 3).

\section{Surgery}

A total of 15 (56.7\%) patients had various surgical interventions. In all, 12 (46.1\%) patients had orthopedic complications, out of which three (11.4\%) patients were provided with thoracolumbar jackets (following pathological fracture of the ribs or thoracolumbar vertebrae) and nine (34.2\%) patients had open reduction and internal fixation (ORIF) on account of pathological fracture of femur and humerus. One (3.8\%) patient had craniotomy following solitary plasmacytoma of frontal bone. One (3.8\%) patient had surgical resection and biopsy of solitary plasmacytoma of jaw (dental) bone. One (3.8\%) patient had resection of solitary plasmacytoma of urinary bladder (Table 3).

\section{Chemotherapy}

A total of $15(57.6 \%)$ patients were treated with melphalan+prednisolone, and one (3.8\%) patient was treated with cyclophosphamide+prednisolone (CP). Two (7.6\%) patients received vincristine+adriamycin+dexamethasone (VAD), five (19\%) patients received melphalan+prednisolo ne+thalidomide (MPT), two (7.6\%) patients received melph alan+prednisolone+bortezomib or Velcade (VMP), and one (3.8\%) patient received cyclophosphamide+vincristine+adria mycin+prednisolone (CVAP). These were the chemotherapy regimens received by the patients.

The survival intervals of the patients based on the chemotherapeutic regimens (VMP, MPT, melphalan-prednisone [MP], VAD, CP, and CVAP) used were 70, 48, 42, 8, 3, and 2 months, respectively. The survival interval of VMP was higher than that of MP and MPT, but it was not statistically significant $(p>0.05)$. However, the survival interval of MP was statistically greater than that of VAD $(p=0.028)$. The overall mean survival interval of the patients was 39.7 months (95\% CI, 32.1-47.2; Table 4).

\section{Radiotherapy}

One $(3.8 \%)$ patient with solitary plasmacytoma of bone (SPB) (frontal bone) underwent radiotherapy. This patient also received chemotherapy and craniotomy.

\section{Stem cell transplantation (autologous)}

One (3.8\%) patient with stage IIIB disease had an autologous stem cell transplantation (ASCT) and was on remission for 24 months; however, he later relapsed and died.

\section{Estimated survival interval of myeloma patients}

A total of 23 (88.5\%) patients were alive after first year of commencement of anti-myeloma chemotherapy, while 20 (77\%) patients, $16(61.5 \%)$ patients, and two (7.6\%) patients lived up to second, third, and fifth year post chemotherapy, respectively (Table 5). 
Table 5 Estimated survival interval of myeloma patients

\begin{tabular}{lll}
\hline $\begin{array}{l}\text { Serial } \\
\text { number }\end{array}$ & $\begin{array}{l}\text { Duration } \\
\text { months (years) }\end{array}$ & $\begin{array}{l}\text { Number of } \\
\text { myeloma } \\
\text { survivors, n (\%) }\end{array}$ \\
\hline 1 & $60(5)$ & $2(7.6)$ \\
2 & $48(4)$ & $12(46)$ \\
3 & $36(3)$ & $16(61.5)$ \\
4 & $24(2)$ & $20(77.0)$ \\
5 & $12(1)$ & $23(88.5)$ \\
\hline
\end{tabular}

\section{Discussion}

The prevalence of MM in the oil-rich Niger-Delta region of Nigeria is on the increase. This may be attributable to a wide range of environmental pollution in the region. The flaring of gases, water pollution, oil spillage, and lack of effective environmental policies could account for this menace. ${ }^{20}$ Occupation studies of cosmetic, chemical, petroleum, and radiation industry workers have provided inconsistent evidence of causal association with MM. ${ }^{1}$

The inability to make early diagnosis of MM poses a great challenge in its management in sub-Saharan Africa. In Nigeria, the diagnosis of MM is usually made after complications have set in. This is evidenced by the long median duration from onset of symptoms to diagnosis. In this study, the median duration from onset of symptoms to diagnosis was 13.12 months with $61.5 \%$ of the subjects presenting with DS clinical stage III. At this stage, prognosis is usually poor and palliative care becomes the best approach to manage such patients.

Chronic bone pain with pathological fracture and anemia appear to be very common end-organ damage of MM in the Niger-Delta region. ${ }^{21,22}$ They are usually managed as orthopedic complications before diagnosis of MM is made. Interleukin-6, an important osteoclast-activating cytokine, plays an important role in the pathogenesis of osteoporosis in MM. ${ }^{23}$ Anemia in MM results from bone marrow invasion by abnormal plasma cells that secrete erythropoiesissuppressive cytokines, leading to anemia of chronic disorder in the patient. ${ }^{24}$

Laboratory investigations of these patients showed anemia, elevated ESR, and increased BMPCs as major hematological findings in this study. In addition, hypergammaglobulinemia, hypoalbuminemia, high creatinine levels, and monoclonal spike in serum protein electrophoresis are the major biochemical findings. This was in keeping with previous studies in the region. ${ }^{25,26}$ Only four subjects could afford immunofixation test, due to prevailing poverty in the country. In addition, this study was able to show an IgA:IgG-type myeloma ratio of 1:3. This is in keeping with previous studies by Salawu and Durosimi ${ }^{22}$ and Fasola et al. ${ }^{26}$ Histologic findings revealed two solitary plasmacytoma of bone (7.6\%) and one extramedullary plasmacytoma (3.8\%) in the patients. The lack of equipment for early diagnosis, staging, and prognostication is the major challenge confronting management of $\mathrm{MM}$ in this region. ${ }^{20,26}$ The prevailing poverty in the region makes it difficult for most patients to afford payment for their treatment, which is usually expensive, and this is another major drawback in the management of $\mathrm{MM}$ in the region..$^{20}$ In order to benefit from the recent advances in the management of MM, equipment for analyzing $\beta 2$ microglobulin (for International Prognostication Staging System), interleukin-6, C-reactive proteins, immunofixation, immunoglobin quantitation and immunophenotyping must be provided by the government to ensure international best practices in the management of MM patients in the region. ${ }^{27}$

All the subjects benefited from analgesics (opiates and NSAIDs) and hematinics as supportive treatment. This is the first supportive therapy offered to myeloma patients who usually present with anemia and bone pain in this region. Only one (3.8\%) patient who had plasmacytoma received radiotherapy. This was lower than that reported by Fasola et $\mathrm{a}^{27}$ in which $20 \%$ of the patients received radiotherapy. Although more patients would have benefited from radiotherapy services, however due to the fact that the service was not available in the centers used for the study and many could not afford the cost of treatment in centers with the facility, the number of subjects who had the treatment was smaller. The presence of plasmacytoma (SPB or extra medullary plasmacytoma [EP]) in an MM patient is usually not common and also indicates poor prognosis. ${ }^{28}$ The prognosis in the patients was further worsened in the absence of radiotherapy, which is the acceptable palliative therapeutic option for MM patients.

A total of $15(56.7 \%)$ patients received different forms of surgery ranging from craniotomy, partial cystectomy to internal fixation of orthopedic pins due to complications arising from myeloma. It was surprising to note that some of these patients had these complications long before the diagnosis of plasma cell myeloma was made. There is paucity of data regarding palliative surgical interventions for people living with myeloma in our region.

Out of $60 \%$ of patients who were severely anemic (hemoglobin concentration $<7 \mathrm{~g} / \mathrm{dL}$ ), $13(50 \%)$ patients received blood transfusion and $10(38 \%)$ patients benefited from recombinant human erythropoietin (rhEPO). Anemia is one of the major challenges confronting management of MM in Nigeria. Blood transfusion is the major supportive interventions used in the region. rhEPO can improve both the 
hemoglobin level and quality of life of patients with MM. The patient with the highest number of blood transfusion received 25 units of blood within a duration of 3 months. However, in addition to blood transfusion that may be associated with transmissible diseases, ${ }^{29}$ erythropoietin was also used to correct the anemia in those patients who could afford it. Three of the patients with severe anemia refused blood transfusion on account of their faith and were treated with rhEPO for the anemia. One of these three patients had the best survival outcome (>70 months).

A total of $10(38 \%)$ patients diagnosed as having $\mathrm{MM}$ were on BPs as supportive therapy for osteolytic bone lesions. This was relatively higher than what was observed by Fasola et $\mathrm{al}^{27}$ in south-west Nigeria. BPs are useful in preventing, reducing, and delaying MM-related skeletal events. These drugs are part of the standard care of patients with lytic lesions. They can also help to control MM tumor growth. The use of BPs is strongly recommended by the International Myeloma Working Group. ${ }^{30}$

Six $(23 \%)$ patients had renal involvement, and five (19.1\%) patients had hemodialysis. This was lower than that reported by Fasola et al in south-west Nigeria and relatively higher than what was reported by Madu et al in south-east Nigeria, where the values were $36 \%$ and $16 \%$, respectively. However, a similar study in the USA by Badros et $\mathrm{al}^{32}$ recorded a $20 \%$ renal complication in MM. Nephropathy in myeloma is one of the late complications of MM, and it connotes poor prognosis. It is generally due to tubular light-chain damage. It could be either reversible or irreversible. The reversibility is dependent on the degree of the light-chain nephropathy, initial therapy, and early plasma exchange. The use of dexamethasone-based regimens preferably with proteasome inhibitors such as bortezomib could ameliorate reversible nephropathy in myeloma. ${ }^{32}$

Three (11.1\%) MM patients with neutropenic sepsis benefited from G-CSF (filgrastim). Infection is one of the major killers in MM, especially when immunosuppression has set in. There is paucity of data regarding treatment of neutropenic sepsis in MM using G-CSF in Nigeria.

This study showed MP as the commonest combined chemotherapeutic regimen used to treat $\mathrm{MM}$ in the region. This could be due to the fact that most of our patients were elderly and MP is still regarded as the standard of care for non-transplant-eligible MM patients in our region based on its relative affordability, accessibility, and better clinical outcome when compared to other first-line anti-myeloma regimens. The VMP triple regimen recorded the highest survival interval of 70 months, while CVAP had the least survival interval. However, there was no significant difference between survival intervals of MP (42 months) and MPT (48 months; $p>0.05$ ). This was contrary to a similar study by Facon et $\mathrm{al}^{34}$ in 2007 where MPT was associated with a significantly better overall survival interval than MP. The role of novel anti-myeloma chemotherapeutic agents in the survival intervals of people living with MM cannot be overemphasized in the current management of MM. Most bortezomib combination chemotherapies have better tolerability profiles and overall survival. VMP is an ideal standard protocol for both transplant- and non-transplant-eligible myeloma patients. However, the major limitations on its use in this region is the cost and accessibility. ${ }^{10}$

One $(3.8 \%)$ of the patients on stage IIIB disease of MM underwent ASCT. However, he died following posttransplantation relapse 2 years thereafter. Stem-cell transplantation involves eliminating a patient's hemopoeitic and immune systems by chemotherapy and/or radiotherapy and replacing it with stem cells either from another individual (allogeneic or syngeneic) or with a previously harvested portion of the patient's own hemopoeitic stem cell (ASCT). Only one $(3.8 \%)$ of the patients could afford this out of 17 $(65 \%)$ patients with DS stage III disease. There is paucity of data regarding stem cell transplantation for MM patients in Nigeria and other sub-Saharan African countries. There is no center that offers ASCT service in Nigeria. Hence, it is a very expensive procedure reserved for the rich. The patients have to travel outside the country to centers where such services are provided. The public health system in Nigeria does not provide insurance coverage for stem cell transplantation. Transplant-eligible patients who require stem-cell transplantation usually pay with their own money. However, in the western world, it is the current trend of management of MM and the survival outcome is good. With the emergence of novel chemotherapeutic agents such as proteasome inhibitors (bortezomib, carfilzomib, and ixazomib), immunomodulatory agents, monoclonal antibodies, and HDAC inhibitors for relapse/refractory $\mathrm{MM}$, the survival interval has improved significantly, especially in developed countries. ${ }^{34,35}$

From this study, it was found that two (7.6\%) of the myeloma patients survived up to 5 years post diagnosis (Table 5). This was below the estimated 5-year period survival of $32 \%$ and $44.9 \%$ recorded by Ries et $\mathrm{al}^{6}$ and Altekruse et $\mathrm{al}^{36}$ in Surveillance, Epidemiology, and End Results (SEER) cancer statistics review of 1975-2002 and 1975-2007, respectively, in the USA. According to 2002 SEER report, the estimated 5-year survival period for White Americans and African Americans 
was somewhat higher in males than in females $(37 \%$ versus $28 \%$, respectively). The 5-year survival period of MM patients in Nigeria was far less than what was obtainable in the USA, due to lack of equipments and poverty in the Niger-Delta region of Nigeria. Hence, much is needed to be done to improve the quality of life of people living with $\mathrm{MM}$ in this region.

\section{Conclusion}

Diagnosis of MM remains a major challenge in sub-Saharan Africa, especially in the Niger-Delta region of Nigeria. This is partly responsible for inconsistent epidemiological data, poor case ascertainment, inadequate palliative care, and major complications encountered by $\mathrm{MM}$ patients in the region. The end results are poor prognostic outcome and low survival interval of MM individuals in the region. There is, therefore, a need to acquire equipment for prompt diagnosis of MM and also to improve the quality of palliative care received by myeloma patients in the region, especially the anti-myeloma treatment protocols that are insufficiently used as very small percentage of our patients could access them. The government, stakeholders in the health institutions, and donor agencies (i.e., passionate groups for $\mathrm{MM}$ ) also have roles to play in the provision of adequate facilities and services for the improvement of the quality of life and lifespan of people living with MM in the Niger-Delta region of Nigeria. There is a need also to have designated centers with modern equipments for the management of MM patients in the six geopolitical zones in Nigeria, with services rendered subsidized by the government and other stakeholders.

\section{Limitations}

This is a retrospective study constrained by a small sample size. It could be possible that some cases (diagnosis) of MM were missed due to lack of equipment and expertise for proper diagnosis, hence contributing to the small sample size.

The patients did not benefit from the New International Prognostic Staging System ${ }^{37}$ due to lack of facility to run $\beta_{2}$ microglobulin test.

In the assessment and treatment of pain in these patients, the WHO analgesic ladder ${ }^{38}$ for cancer pain control was not strictly adhered to as only very few centers were able to access oral morphine and other opiate analgesics at the time of the treatment.

Supportive care in palliative medicine should take cognizance of psychosocial therapies. However, these were not captured in this study. This could be due to the fact that this retrospective study did not preclude the latter in the management of the patients and for the fact that palliative care was at its primordial stage in this part of the world at the time of this study. Further research is needed to corroborate these findings and to bring the holistic aspect of palliative care into play.

\section{Acknowledgments}

The authors wish to thank the management and the departments of Haematology, Surgery, and Medicine of UPTH; Braithwaith Memorial Hospital, Port Harcourt, Nigeria; FMC, Umuahia, Nigeria; and Abia State University Teaching Hospital, Aba, Nigeria, for creating enabling environment for this research work.

\section{Disclosure}

The authors report no conflicts of interest in this work.

\section{References}

1. Alexander DD, Mink PJ, Adami H, et al. Multiple myeloma: a review of the epidemiologic literature. Int J Cancer. 2007;120(suppl 12):40-61.

2. Parkin DM, Bray F, Ferlay J, Pisani P. Global cancer statistics, 2002. CA Cancer J Clin. 2005;55(2):74-108.

3. Mahindra A, Hideshima T, Anderson KC. Multiple myeloma: biology of the disease. Blood Rev. 2010;24(suppl 1):S5-S11.

4. Rajkumar SV, Kyle RA. Multiple myeloma: diagnosis and treatment. Mayo Clin Proc. 2005;80(10):1371-1382.

5. Parkin DM, Whelan SL, Ferlay J, Teppo L, Thomas DB. Cancer in Five Continents. Vol. VIII. Lyon: IARC; 2002. IARC Scientific Publication No. 155.

6. Ries LAG, Eisner MP, Kosary CL, et al [webpage on the Internet]. SEER Cancer Statistics Review, 1975-2002. Bethesda, MD: National Cancer Institute; 2005. Based on November 2004 SEER data submission, posted to the SEER web site 2005; Myeloma section. Available from: http:// seer.cancer.gov/csr/1975_2002/. Accessed April 14, 2017.

7. Landgren O, Kyle RA, Pfeiffer RM, et al. Monoclonal gammopathy of undetermined significance (MGUS) consistently precedes multiple myeloma. A prospective study. Blood. 2009;113(22):5412-5417.

8. Blair CK, Cerhan JR, Folsom AR, Ross JA. Anthropometric characteristics and risk of multiple myeloma. Epidemiology. 2005;16(5):691-694.

9. Brown LM, Gridley G, Pottem LM, et al. Diet and nutrition as risk factors for multiple myeloma among blacks and whites in the United States. Cancer Causes Control. 2001;12(2):117-125.

10. Nwabuko CO, Nnoli MA, Okoh DA, John EJ, Chukwuonye II. Survival outcome of multiple myeloma patients on chemotherapeutic regimens in the Niger-delta Nigeria. Int J Recent Sci Res. 2015;6(6):4889-4893.

11. Nwabuko CO, Nnoli MA, Igbigbi EE, Okoh DA, Chukwuonye II. Survival outcome of double and triple-only combination anti-myeloma chemotherapeutic regimens on 26 multiple myeloma patients seen in a Sub-Saharan African Country. Blood. 2014;124:5755. [ASH Abstract, 2014].

12. International Myeloma Working Group. Criteria for the classification of monoclonal gammopathies, multiple myeloma and related disorders: a report of the International Myeloma Working Group. Br J Haematol. 2003;121(5):749-757.

13. Kyle RA, Durie BG, Rajkumar SV, et al. Monoclonal gammopathies of undetermined significance (MGUS) and smouldering (asymptomatic) multiple myeloma: IMWG consensus perspectives risk factors for progression and guidelines for monitoring and management. Leukaemia. 2010;24(6):1121-1127.

14. Sepulveda C, Marlin A, Yoshida T, Ulrich A. Palliative care: the World Health Organisation's global perspective. J Pain Symptom Manage. 2002;24:91-96. 
15. Nwabuko CO, Nnoli MA. The benefits of antiretroviral therapy in palliative care in developing nations. IOSR J Environ Sci Toxicol Food Technol. 2013;2(6):72-74.

16. Federal Republic of Nigeria. Niger Delta Regional Development Master Plan. Available from http://www.nddc.gov.ng/NDRMP\%20 Chapter\%201.pdf. Accessed May 11, 2017.

17. Oken MM, Creech RH, Tormey DC. Toxicity and response criteria of the Eastern Cooperative Oncology Group. Am J Clin Oncol. 1982;5(6): 649-655.

18. Evangelos T, Amin R. Myeloma. In: Hoffbrand AV, Catovsky D, Tuddenham EG, editors. Postgraduate Haematology. 5th ed. Oxford: Blackwell; 2005:681-702.

29. Durie BGM, Salmon SE. A clinical staging system for multiple myeloma: correlation of measured myeloma cell mass with presenting clinical features, response to treatment and survival. Cancer. 1975;36(3): 842-854.

20. Nwabuko CO, Nnoli MA, Igbigbi EE. Plasma cell myeloma: challenges in diagnosis in sub-Saharan Africa. Jokull J. 2015;65(1):254-266.

21. Salawu L, Durosimi MA. Myelomatosis: clinical and laboratory features in Nigeria. West Afr J Med. 2005;24(1):54-57.

22. Madu AJ, Ochenis S, Nwagha TA, Ibegbulam OG, Anike US. Multiple myeloma in Nigeria: an insight to the clinical, laboratory features, and outcomes. Niger J Clin Pract. 2014;17(2):212-217.

23. Garret JR, Durie BGM, Nedwin GE, et al. Production of lymphotoxin, a bone resorbing cytokine by cultured human myeloma cells. $N$ Eng $J$ Med. 1989:317(9):526-532.

24. Beguin Y, Yerna M, Loo M, Weber M, Fillet G. Erythropoiesis in multiple myeloma: defective red cell production due to inappropriate erythropoietin production. Br J Haematol. 1992;82(4):648-653.

25. Omoti C, Halim NKD. Plasma cell myeloma in a Tertiary Center in Niger-Delta Region of Nigeria: clinico-immunologic analysis. Pak J Med Sci. 2007;23(1):27-32.

26. Fasola FA, Eteng K, Akinyemi JO. Multiple myeloma: challenges of management in a developing country. J Med Med Sci. 2008: $397-403$.
27. Dispenzieri A, Kyle RA. Multiple myeloma: clinical features and indications for therapy. Best Pract Res Clin Haematol. 2005;18(4):553-568.

28. Kar, M, Roy R, Chakraborty,J, Das S. Extramedullary plasmacytoma-a rare presentation. Journal, Indian Academy of Clinical Medicine. 2008; 9(4): 229.

29. Nwabuko CO, Nnoli MA, Okoh DA, Chukwuonye II. Taming the tide of HIV and TTI Scourge in sub-Saharan Africa using autologous blood transfusion. Haematol Leukemia. 2013;1(7):doi: 10.7243/2052-434x-1-7.

30. Evangelos T, Gareth M, Meletios AD, et al. International Myeloma Working Group recommendations for the treatment of multiple myeloma-related bone disease. J Clin Oncol. 2013;31(18):2347-2357.

31. Badros A, Barlogie B, Siegel E, et al. Results of autologous stem cell transplant in multiple myeloma patients with renal failure. $\mathrm{Br} J \mathrm{Hae}$ matol. 2001;114(4):822-829.

32. Joan B, Laura R. Renal, haematologic and infections complications in multiple myeloma. Best Pract Res Clin Haematol. 2005;18(4):635-652.

33. Facon T, Mary JY, Huliu C, et al. Melphalan and prednisone plus thalidomide versus melphalan and prednisone alone or reducedintensity autologous stem cell transplantation in elderly patients with multiple myeloma (IFM 99-06): a randomised trial. Lancet. 2007;370(9594):1209-1218.

34. Kumar SK, Rajkumar SV, Dispenzieri A, et al. Improved survival in multiple myeloma and the impact of novel therapies. Blood. 2008;111(5):2516-2520.

35. Richardson PG, Mitsiades C, Schlossman R, Munshi N, Anderson K. New drugs for myeloma. Oncologist. 2007;12(6):664-689.

36. Altekruse SF, Kosary CL, Krapcho M [webpage on the Internet]. SEER Cancer Statistics Review. 1975-2007. Bethesda: National Cancer Institute; 2010. Available from: seer.cancer.gov/statfacts/html/mulmy.html. Accessed April 14, 2017.

37. Greipp PR, Miguel JS, Durie BGM, et al. International staging system for multiple myeloma. J Clin Oncol. 2005;23(15):3412-3420.

38. World Health Organization. Traitement de la douleur cancereuse. Geneva: World health Organization; 1987.
Cancer Management and Research

\section{Publish your work in this journal}

Cancer Management and Research is an international, peer-reviewed open access journal focusing on cancer research and the optimal use of preventative and integrated treatment interventions to achieve improved outcomes, enhanced survival and quality of life for the cancer patient. The manuscript management system is completely online and includes

\section{Dovepress}

a very quick and fair peer-review system, which is all easy to use. Visi http://www.dovepress.com/testimonials.php to read real quotes from published authors. 